УДК 504.03-029:1

DOI: $10.21779 / 2500-1930-2018-33-4-82-86$

\title{
К.М. Алилова
}

\section{Христианство и ислам в решении экологических проблем}

Дагестанский государственный университет; Россия, 367001, 2. Махачкала, ул. М. Гаджиева, 43a; kalimat2@mail.ru; Дагестанский государственный университет народного хозяйства; Россия, 367008, Республика Дагестан, г. Махачкала, ул. Д. Атаева, 5

В статье рассматривается проблема взаимодействия религии и экологии. XXI век - это век решения одной из самых насущных проблем человечества - спасения природы. Для ее решения необходимо объединение всех активно думающих людей, не исключая представителей духовенства. Например, христианство способно оказать позитивное влияние в решении экологического кризиса, являясь одним из источников формирования экологической этики. Однако многие теологи считают, что оно ориентировано на порабощение природы, а человек себя возвеличил и противопоставил всему остальному миру. В то же время в христианстве есть много положений о том, что природа есть вместилище ресурсов, предназначенных не для эгоистического и безответственного потребления, природа - это дом, где человек является не хозяином, а мудрым домоправителем. В Священном Писании есть заветы Бога для людей, как им следует поступать друг с другом и с окружающим миром, чтобы не разрушать его.

Ислам тоже обосновал свое отношение к вопросам экологии. Исламские законы ограничивали активное вмешательство человека в природу. Это отражено в 750 аятах Корана, поэтому ислам, как и большинство других религий, призывает изучать проблемы взаимоотношений человека и природы. Ислам поможет понять, что контроль человека над миром небезграничен и его потребительское отношение к природе может быть направлено в конечном итоге против него самого.

В данной работе показан экологический аспект в христианстве и исламе, социальнофилософский смысл которого предполагает выяснение области взаимодействия экологии и религии, анализ и поиск путей возрождения и распространения традиций охраны природы, заложенных в различных религиозных системах.

Актуальность данной работы в том, что экология должна стать парадигмой современного диалога цивилизаций и основой межкультурных взаимодействий. Понимание соотношения религиозных традиций с природообразующей деятельностью человека чрезвычайно важно, когда эта деятельность оказывает разрушающее действие на природу. Поэтому опора на духовные ценности всех религий может сыграть значительную роль в формировании экологического мировоззрения, сформировать у людей правильное отношение к окружающей его природе на основе общечеловеческих ценностей, в том числе и религиозных традиций.

Ключевые слова: Библия, Коран, христианство, ислам, природа, экологические проблемы, религиозные традищии.

22 апреля - Международный день Земли. Праздник отмечают под эгидой ООН, чтобы привлечь человечество к проблемам окружающей среды. Недаром Р. Рождественский, русский поэт, публицист, писал:

Леса без птиц

И земли без воды.

Всё меньше

окружающей природы,

Всё больше - окружающей среды.

82 Вестник Дагестанского государственного университета.

Серия 3. Общественные науки. 2018. Том 33. Вып. 4 
Ученые разных мировоззрений говорят о том, что человеческая цивилизация находится в состоянии беспрецедентного экологического кризиса, который можно остановить только мобилизуя материальные и духовные ресурсы человечества. Современная цивилизация привела к разрушению системы «общество-природа». Отношения человека с окружающей средой не отличаются стабильностью. Они выражены в деструктивном начале, результатом которого является углубление глобальных экологических проблем на Земле [6]. В связи с этим необходим поиск точек соприкосновения для решения самого главного вопроса современности - сохранения жизни на планете. Для этого важно сблизить культуру, науку и религию.

По мнению многих исследователей, улучшение экологической ситуации по существу зависит от возрождения духовных ценностей, к которым можно отнести и религиозно-этические нормы. Именно духовно-нравственные ценности являются той живой субстанцией, внутри которой человек раскрывает и развивает себя посредством природы, а природа раскрывает и развивает себя посредством человека [2, с. 101].

Еще Патриарх Московский и всея Руси Алексий II говорил, что «общей нашей задачей является сохранение единства, возрождение нравственных основ, потому что хищническое отношение к природе, к окружающей среде - это безнравственно» [1].

В XXI в. экологические проблемы стали намного серьезнее. Для усиления своего влияния среди верующих христианские мыслители начали активно решать проблемы, затрагивающие все человечество. Данные проблемы, по мнению самих богословов, оказались очень ценным аргументом в пользу проповеди «смирения». «Могущество нашего господства над природой опьянило нас, мы сочли себя всесильными, - пишет теологический эколог Г. Зигвальт, - наши нынешние трудности есть следствие горделивого забвения трансценденции» [5].

Современные христианские теологи считают, что будущее человечества должно быть связано с духовным обновлением, на этом оно и фокусирует свое предназначение. Это подтверждают и мусульманские теологи. Возникло предположение, что возрождение значимости природы связано с авторитетом ученых-теологов различных конфессий, так как в условиях усиления религиозного влияния к ним прислушиваются миллионы людей в разных странах, т. е. речь идет о разумном воздействии на этический климат современной эпохи.

В ранних работах А.Д. Иоселиани вела речь о том, что библейские тексты можно расценивать как протоэкологические, в которых есть суждения о том, что природа, которую Бог дал человеку, должна быть защищена. В подтверждение этой мысли можно привести слова из Библии, которые звучат как призыв движения «зеленых»: «Не порти дерев его (завоеванного города), от которых можно питаться, и не опустошай окрестностей; ибо дерево на поле не человек, чтобы могло уйти от тебя в укрепление» (Ветхий Завет. Второзаконие Моисея 20:19) [4, с. 106].

Христианская экологическая этика утверждает: люди могут владеть землей ради своей пользы, но при этом необходимо нести ответственность за природу. Они должны быть не ее разрушителями, а хранителями. Бог создал все на благо человека. Но противоречивость христианства выражается в том, что в основе его традиции лежит ориентация на преобразование всей окружающей природы. Здесь от христианина требуются активная позиция, действие. Однако осуществлять свое владычество над природой надо «мудро и с любовью». Поэтому основанные на Библии христианские ценности должны формировать у человека экологическое сознание.

Многие тексты Библии «экологичны» сами по себе. Но система «Бог - человек» характеризуется как антропоцентрическая. Из этого следует, что христианская мысль о возможности покорения человечеством природы утвердилась в инвайронментализме. По мнению христианских мыслителей, человек был введен в этот мир как господин в 
дом, как священнослужитель в божий храм, что и определило его отношение к среде обитания не только как владыки, но и как заботливого хозяина природы.

В Библии есть предупреждение человечеству о неизбежной глобальной катастрофе, к которой цивилизация подводит самое себя. С точки зрения науки это означает, что если будут исчерпаны необходимые условия для жизни на планете и в ее слоях (атмосфере, гидросфере, литосфере), то, естественно, исчезнет и все биологическое, в том числе и человек $[4$, с. 106$]$.

По мнению христианских авторов, именно нарушение библейских заповедей есть причина многих сегодняшних экологических бед. Поэтому христианские нравственные принципы (любовь к природе, к человеку, гуманность, сострадание т. д.) могут лечь в основу формирования современной экологической культуры. Христианство может внести немалый вклад в решение проблемы обеспечения глобальной экологической безопасности, несмотря на многообразие подходов к данной проблеме.

Сегодня Русская православная церковь предлагает в качестве меры по преодолению экологического кризиса возрождение христианского аскетизма по отношению к природе, для этого необходимо воспитывать ответственность христианина за состояние окружающей среды [7].

Исламская традиция утверждает, что человек и окружающий мир зависят от Бога, потому люди не должны вмешиваться в природные процессы; являясь вершиной божественного творения, человек должен охранять природу. Большинство мусульманских стран находится в зоне с ограниченным экологическим потенциалом. В исламе существуют предписания о наказании за нарушение его законов (экологи в этом случае обычно говорят о нарушении законов природы). Законы ислама требуют благоговейного отношения к воде: большим грехом считается неумеренное ее потребление.

Ислам в большей мере, чем христианство, способствовал сохранению традиционного общества земледельца, где решение проблем цивилизации осуществляется на уровне обыденной жизни [4, с. 110]. В нем есть уникальный набор моральных ценностей и эколого-этических правил для корректировки отношений между людьми и окружающей природой; предусмотрены суровые наказания для тех, кто не обращается с природой должным образом. Современному миру необходима такая суровая философско-экологическая этика.

Для решения экологических проблем возможно использование такого уникального явления, как суфизм. Он рассматривается как религиозный аскетизм, теоретической базой которого является синтез ортодоксального ислама и различных немусульманских философских школ - неоплатонизма, буддизма и т. д. [3]. Указывается, что знать стала отходить от аскезы, предписанной в Коране, предавалась излишествам, поэтому суфизм внес в мусульманскую общину идеалы скромного и благочестивого образа жизни. Такие идеи ориентируют человечество на умеренность в потреблении природных ресурсов, поэтому и сегодня они актуальны и могут быть использованы и экологами, и философами.

Согласно исламской традиции у человека нет неограниченной власти над природой, поэтому он не должен наносить ей вред. В Коране нет стихов, утверждающих, что природа «находится под ногами человека». В этом, на наш взгляд, существенное различие исламской экологической этики от христианской.

Таким образом у мусульман возникает потребность жить в гармонии с природой. Идеология ислама имеет аналоги с иудео-христианским учением. Так как ислам возник позже других религий, он не мог не впитать в себя библейские идеи, что говорит о его единстве с христианством.

Во многих мусульманских странах идея о том, что человечеству необходимо избегать чрезмерного потребления и избыточного производства, набирает обороты, так как это осуждаемое Кораном расточительство. Некоторые шариатские установки (закят и

84 Вестник Дагестанского государственного университета.

Серия 3. Общественные науки. 2018. Том 33. Вып. 4 
риба) как регуляторы хозяйственных отношений дают возможность их участникам соблюдать нормы ислама, для которого характерны чистота и умеренность в потреблении.

Известный мусульманский ученый Мухаммед Ниджатулла Сиддики отмечал, что мусульманину следует проявлять умеренность в покупках, избегать предметов роскоши и пустых трат. Современная экономика, заключал он, должна воспринять исламские ценности. Шариату надлежит быть сводом правил «экономического стиля поведения и действия» [8].

По мнению исламских теологов, человек, присваивая себе право вмешиваться в дела Божьи, виноват в проблемах, от которых сам же и страдает. В этом смысле ценностям ислама может отводиться значительная роль в формировании экологической культуры верующих.

Духовные лидеры многих стран считают необходимым, используя средства массовой информации, убеждать людей, что духовная нищета является началом смерти человечества. Единственный выход - незамедлительно принять меры для повышения духовно-нравственного уровня представителей всех конфессий и категорий населения.

Религия является уникальной формой общественного сознания, играет важнейшую роль в жизни множества людей. Человеку присущи религиозные чувства, стремление к самопознанию, поиску смысла жизни; в этом поиске одни обращаются к науке, другие - к материальным благам, третьи - к искусству, многие же - к религии [4].

В заключение можно утверждать, что религия как массовое сознание может играть важную роль в провозглашении единства человека и природы. Ученые и теологи должны быть тесно связаны: первые говорят о состоянии окружающей среды, путях решения экологических проблем, теологи же «пробуждают людскую совесть».

В борьбе за мир сегодня объединились атеисты и верующие, люди доброй воли, все слои общества и все конфессии. Посредством взаимодействия науки и религии человечество сможет с уважением относиться к природе, используя современные технологии. Религия может выступать в качестве важного фактора, способствующего утверждению и проявлению персоноцентристского характера новой, постиндустриальной цивилизации, которая впервые в истории на базе достижений НТР и успехов в демократизации общественной жизни закладывает реальные предпосылки осуществления извечных гуманистических идеалов, что в свою очередь является условием выживания человечества.

Великий Леонардо да Винчи писал: «В природе все мудро продумано и устроено, всяк должен заниматься своим делом, и в этой мудрости высшая справедливость жизни». Над этим высказыванием стоит задуматься, так как это не просто цитата, а призыв к жизни, где любовь к природе является основой существования жизни на земле.

\section{Литература}

1. Алексий II (Ридигер). Не противостоять, а объединять усилия // Русский вестник. - 1992. - № 49. - С. 5.

2. Алилова K., Алилов А. Религиозная этика и глобальная экология // Свободная мысль. - 2011. - № 11. - С. 109.

3. Билалов М.И. Дагестан в культуре и цивилизации. - Махачкала, 2010. - С. 110.

4. Иоселиани А.Д. Экологическое сознание и религиозные ценности в священнописаниях Востока // Философия и общество. - 2014. - № 3. - С. 105-110.

5. Круглова Г.А. Философский анализ основных концепций христианской глобалистики // Вестник ВолГУ. Сер. 7. - 2008. - № 1 (7) - С. 185.

6. Кулиев T. Экологический компонент в христианстве: пути изучения // Родник. Махачкала, 2010. - Вып. 11. - С. 20. 
7. Кулебякин Е.В., Замялова Н.И. Особенности подхода современного русского православия к пониманию и преодолению экологического кризиса // Гуманитарные исследовании в Восточной Сибири и на Дальнем Востоке. - 2012. - № 3 (19). - С. 96.

8. Siddiki M. An Islamic Apporoach to Economics // At Tauhid. - Tehran. - 1987. Vol. 4, № 2. - P. 118.

Поступила в редакцию 3 октября 2018 г.

UDC 504.03-029:1

DOI: $10.21779 / 2500-1930-2018-33-4-82-86$

\title{
Christianity and Islam in solving environmental problems
}

\author{
K.M. Alilova \\ Dagestan State University; Russia, 367001, Makhachkala, M. Gadzhiev st., 43a; \\ kalimat2@mail.ru; \\ Dagestan State University of National Economy; Russia, 367008, Makhachkala, Ataev st., 5
}

The article deals with the problem of interaction between religion and ecology. The 21 st century is the century of solving one of the most pressing problems of the mankind - saving nature. To solve this problem, it is necessary to unite all actively thinking people, not excluding members of the clergy. For example, Christianity is able to exert a positive influence in solving the environmental crisis, being one of the sources for the formation of environmental ethics. However, many theologians believe that it is focused on the enslavement of nature, and man exalted himself and opposed to the rest of the world. At the same time, there are many provisions in Christianity that suggest that nature is a repository of resources intended not for selfish and irresponsible consumption, but as a house where a person is not a master, but a wise steward. In Scripture there are the precepts of God for people, how they should interact with the world around, so as not to destroy it.

Islam also justified its attitude to the environmental issues. Islamic laws have always negatively evaluated the active intervention of man in nature. This is reflected in 750 verses of the Qur'an, therefore Islam, like the majority of other religions, appeals to study and reflect on the problems of the relationship between man and nature. Islam will help to understand that man's control over the world is not limitless, and that his consumer attitude towards nature can be directed, ultimately, against himself.

This paper shows the environmental aspect in Christianity and Islam, the socio-philosophical meaning, which involves finding out the area of interaction between ecology and religion, analyzing and searching for ways to revive and spread the traditions of nature conservation laid down in various religious systems.

The relevance of this work is that the ecology should become the paradigm of the modern dialogue of civilizations and the basis of intercultural interactions. Understanding the relationship of religious traditions with nature-forming human activity is extremely important, especially when this activity has a destructive effect on nature. Therefore, reliance on the spiritual values of all religions can play a significant role in shaping the ecological world outlook, form the right attitude of people towards its environment on the basis of universal human values, including religious traditions.

Keywords: the Bible, the Koran, Christianity, Islam, nature, environmental problems, religious traditions.

Received 3 October, 2018 